\title{
Effect of Domestic Wastewater as Co-Substrate on Biological Stain Wastewater Treatment Using Fungal/Bacterial Consortia in Pilot Plant and Greenhouse Reuse
}

\author{
Pedroza-Camacho Lucas David1, Lores-Acosta Juan Camilo², Rojas-Enríquez Johans Farid, \\ Mateus-Maldonado Juan Felipe ${ }^{3}$, Puentes Cindy Stephanie ${ }^{2}$, Ramírez-Rodríguez Julio², \\ Mendez-Casallas Francy Janeth ${ }^{2}$, Salcedo-Reyes Juan Carlos ${ }^{4}$, Díaz-Ariza Lucía Ana ${ }^{5}$, \\ Lozano-Puentes Hair Santiago5, Pedroza-Rodríguez Aura Marina ${ }^{3}$
}

\begin{abstract}
${ }^{1}$ Programa de Biología. Departamento de Ciencias Básicas, Universidad de La Salle, Bogotá, D.C., Colombia ${ }^{2}$ Facultad de Ingeniería, Departamento de Ingeniería Ambiental, Universidad de La Salle, Bogotá, D.C., Colombia ${ }^{3}$ Laboratorio de Microbiología Ambiental y de Suelos, Grupo de Biotecnología Ambiental e Industrial, Departamento de Microbiología, Facultad de Ciencias, Pontificia Universidad Javeriana, Bogotá, D.C., Colombia

${ }^{4}$ Laboratorio de Películas Delgadas y Nanofotonica, Departamento de Física, Facultad de Ciencias, Pontificia Universidad Javeriana, Bogotá, D.C., Colombia

${ }^{5}$ Laboratorio Asociaciones suelo, planta microorganismos (LAMIC), Grupo de Investigación en Agricultura Biológica, Departamento de Biología, Facultad de Ciencias, Pontificia Universidad Javeriana, Bogotá, D.C., Colombia

Email:1pedroza16@unisalle.edu.co, jlores00@unisalle.edu.co, johans.rojas@javeriana.edu.co, juan-mateus@javeriana.edu.co, cpuentes16@unisalle.edu.co, jcramirez@unisalle.edu.co,fmendez@unisalle.edu.co, luciaana@javeriana.edu.co, h.lozano@javeriana.edu.co, salcedo.juan@javeriana.edu.co, apedroza@javeriana.edu.co
\end{abstract}

How to cite this paper: David, P.-C.L., Camilo, L.-A.J., Farid, R.-E.J., Felipe, M.-M.J., Stephanie, P.C., Julio, R.-R., Janeth, M.-C.F., Carlos, S.-R.J., Ana, D.-A.L., Santiago, L.-P.H. and Marina, P.-R.A. (2018) Effect of Domestic Wastewater as Co-Substrate on Biological Stain Wastewater Treatment Using Fungal/Bacterial Consortia in Pilot Plant and Greenhouse Reuse. Journal of Water Resource and Protection, 10, 369-393. https://doi.org/10.4236/jwarp.2018.103020

Received: February 8, 2018 Accepted: March 26, 2018 Published: March 29, 2018

\begin{abstract}
In this study, a pilot wastewater treatment plant was used to evaluate the co-treatment of biological-staining residues and domestic wastewater under non-sterile conditions. A novel microbial consortia formed by Trametes versicolor, Trametes sp, Pleurotus ostreatus, Pseudomonas fluorescens, Pseudomonas azotoformans, Pseudomonas sp, Enterobacter xianfangensis and Bacillus subtillis was inoculated in an extended aeration type bio-reactor. The treatment units were operated during three consecutive cycles during a period of $147 \mathrm{~h}$. After the last operating cycle, the concentrations of Chemical Oxygen Demand, Biochemical Oxygen Demand, Color Units, Total suspended solids, and the $\mathrm{pH}$ value were $1695 \mathrm{mg} / \mathrm{L}, 105 \mathrm{mg} / \mathrm{L}, 106 \mathrm{CU},<0.001 \mathrm{mg} / \mathrm{L}$ and 5.8 respectively. The initial values of wastewater were $6755 \mathrm{mg} / \mathrm{L}$ (COD), 2005 $\mathrm{mg} / \mathrm{L}\left(\mathrm{BOD}_{5}\right), 1367(\mathrm{CU}), 566 \mathrm{mg} / \mathrm{L}(\mathrm{TSS})$ and $7.0(\mathrm{pH})$ respectively. The reduction of pollutants load was related with the ratio of the two types of wastewater (3.5:0.5) combined to increase biodegradability, the concentration
\end{abstract}


Copyright () 2018 by authors and Scientific Research Publishing Inc. This work is licensed under the Creative Commons Attribution International License (CC BY 4.0).

http://creativecommons.org/licenses/by/4.0/ of fungi and bacteria used in the consortia $\left(30 \times 10^{3}-55 \times 10^{6} \mathrm{CUF} / \mathrm{mL}\right.$ Total Fungi and $70 \times 10^{7}-83 \times 10^{8} \mathrm{CFU} / \mathrm{mL}$ of Total Bacteria) and ligninolytic enzymes production, Laccase (13 - $96 \mathrm{U} / \mathrm{L}), \mathrm{MnP}(9.8-39 \mathrm{U} / \mathrm{L})$ and $\mathrm{LiP}(0.3-$ $5.3 \mathrm{U} / \mathrm{L})$. The post-treated effluent was used as irrigation water. Lolium perenne plants were watered during 60 days with post-treated effluent. The results of root weight showed that there are significant differences between the initial water and the effluent obtained after the operational cycles $(\mathrm{p}=$ $0.00470)$. The highest root weights $(1-1.12 \mathrm{~g})$ were found in plants irrigated with water obtained from the last treatment cycle.

\section{Keywords}

Fungal/Bacterial Consortia, Biological Staining and Domestic Wastewater Co-Treatment and Irrigation Reuse

\section{Introduction}

Hospitals, Universities, and Research Centers are public service providers that generate every day considerable volumes of Domestic Wastewater (DWW) and Non-Domestic Wastewater (NDWW). Generally speaking, most of these institutions accumulate and store NDWW in special containers that are collected by companies specialized in its neutralization and final disposal. Despite implementing waste management programs, occasionally small volumes of NDWW could be mixed with DWW and be released to the sewage system. This represents a risk for receiving water bodies due to the chemical complexity of NDWW that may contain potentially dangerous substances such as dyes, endocrine-disruptors, pharmaceutical compounds, organic pollutants and pathogenic microorganisms resistant to antimicrobial [1] [2] [3] [4].

The presence of these compounds in NDWW increases the concentration of Chemical Oxygen Demand (COD), Biochemical Oxygen Demand $\left(\mathrm{BOD}_{5}\right)$, Total Suspended Solids (TSS), Units of Color (UC), microbial population, and $\mathrm{pH}$, making of this type of wastewater a liquid residue particularly difficult to treat. Hence, it is important to find physicochemical or biological unitary processes or operations that can be fast, economically affordable and active even in the presence of certain contaminants [5] [6] [7]. This implies that different productive sectors, educational and public services providers of sewerage, must improve or implement more rigorous sanitation and management plans to ensure the removal pollutant efficiency and comply with regulatory requirements, maintain environmental licensing, sewage discharge permission and evaluate possibilities for treated wastewater reuse, since quality and supply have been decreased in recent years. These changes are evident in Colombian regulation, with resolution 0631 issue by Ministry of Environment and Sustainable Development [8], resolution 3957 and 1207 by Secretary of Distrital for Environment [9]. The first two establish permissible limits to disposable wastewater into a water body or a se- 
werage system in the Colombian country (first resolution) or only for Bogota city (second resolution). The third resolution adopts disposables related to the use of treated wastewater. All three were established in order to improve wastewater treatment, ensure effective control of pollution, promote sustainable development and be in accordance with international standards. Because the need to have more efficient and economic technologies that allow companies perform the new environmental policies, physical, chemical and biologic alternatives has been explored. Among biological alternatives, the use of the fungal and bacterial consortia can be utilized for increasing the removal efficiency in treatment plants of this kind of wastewater [11]. Among these systems, the use of ligninolytic fungi in association with heterotrophic, mesophilic and aerobic bacteria represents a viable option. The success of the consortia is based on synergic interactions. First, fungi transform colorants and other aromatic compounds into less complex products eventually used by bacteria [12]. White Rot Fungi modifies aromatic compounds by producing unspecific enzymes such as Laccases and Peroxidases [13] [14]. These enzymes act on chemical structures similar to lignin which is their natural substrate. Other enzymes produced by the same type of fungi (Aryl alcohol oxidase, glyoxal oxidase and aryl alcohol dehydrogenase) contribute to the transformation process by creating co-factors such as Hydrogen Peroxide. This chemical agent is responsible for the activation of peroxidases compound I, and also triggers biologic Fenton-like reactions that end in the production of highly reactive oxygen species [15] [16]. These chemical species play a role in the non-enzymatic degradation of lignin and aromatic compounds such as dyes [13] [17].

Furthermore, aerobic bacteria may degrade aromatic compounds or aliphatic by-products by releasing various enzymatic systems like the mono-oxygenases, di-oxygenases, tyrosinases, hexane-oxydases and aminopyrine $\mathrm{N}$-demethylase [12] [18] [19]. Some studies found that certain dyes may induce the bacterial production of Lignin Peroxidase and Manganese Peroxidase [20] [21]. The combined action of fungi and bacterial enzymes and the adsorption process to the microbial cell-wall could improve substantially the removal of pollutants with a variety of chemical structures.

Occasionally, nutritional modifications to wastewater are made by adding nutrient solutions or liquid sub products before starting the actual treatment. This is due to the complexity of the liquid residues (NDWW) and the lack of easily available sources of carbon, nitrogen and other nutrients that can be taken by microorganisms [22]. This alternative might be viable but it increases the costs of treatment. Another less explored possibility implies the use of DWW as co-substrate of degradation. DWW represents a rich source of nutrients, like organic matter, several forms of nitrogen and organic phosphorus that are more biodegradable than NDWW or landfill leachates [23] [24]. A combination of wastewater to make a co-treatment represents a sustainable environmental solution since it uses two types of wastewater that can be depurated in treatment 
plants. Moreover, the final effluent may be used in irrigation systems of plants not consumed directly or indirectly by humans or animals [10].

The present study evaluated novel microbial consortia at pilot plant scale, formed by Trametes versicolor, Trametes sp, Pleurotus ostreatus, Pseudomonas fluorescens, Pseudomonas azotoformans, Enterobacter xianfangensis and Bacillus subtillis for the co-treatment of Biological-staining wastewater (BSWW) and domestic wastewater (DWW). Additionally, post-treated wastewater was used for irrigating ryegrass perenne at greenhouse scale. This plant is extensively used in several countries as an alternative for recreational areas and recuperation of degraded soils. It possesses a fast germination and growth rate [25]. It has a moderate tolerance to salinity and depending on the variety it shows a good growth in soils with Electric Conductivity (EC) of $3 \mathrm{dS} / \mathrm{m}$ [26]. The use of the effluents derived from the plant treatment evaluated in this study represents an alternative of reuse in recreational areas and gardens.

\section{Materials and Methods}

\subsection{Microorganisms}

Fungi Pleurotus ostreatus (HPB/P3), Trametes versicolor (HPB/T2), Trametes sp. (HPB/T6) and Bacteria (Pseudomonas fluorescens, Pseudomonas azotoformans, Enterobacter xianfangensis and Bacillus subtilis) were obtained from the microbial collection of the laboratory of Environmental and Soil Microbiology (Pontificia Universidad Javeriana, Bogota, Colombia). Fungi reactivation was performed following the methodology reported by Morales et al. [27]. Bacteria reactivation was done following the protocol recorded by Mesa et al. [28].

\subsection{Production of Microbial Cosortio (Fungi/Bacteria) Used in Bio-Reactor Tests}

The fungal inoculum was obtained by individually adding 5 disc of EST agar colonized (7 days) by each fungus to Erlenmeyer flasks $(250 \mathrm{~mL})$ containing 100 $\mathrm{mL}$ of wheat bran extract broth (WBEB) [25]. The Erlenmeyer flasks were orbital-shaken during 7 days at $30^{\circ} \mathrm{C}$ and $120 \mathrm{rpm}$. Pellets formation was observed at the end of incubation time. Scale-up was performed in pneumatic bio-reactors of $6 \mathrm{~L}$ with working volumes of $5 \mathrm{~L}$. WEBEB media was modified by the authors (Wheat bran 17 g/L, Glucose $10 \mathrm{~g} / \mathrm{L}$, Yeast extract $2 \mathrm{~g} / \mathrm{L}$, Tryptose $5 \mathrm{~g} / \mathrm{L}, \mathrm{KH}_{2} \mathrm{PO}_{4}$ $0.1 \mathrm{~g} / \mathrm{L}, \mathrm{MgSO}_{4} 0.05 \mathrm{~g} / \mathrm{L}, \mathrm{MnSO}_{4} 0.76 \mathrm{~g} / \mathrm{L}$ and $\mathrm{pH}$ 6.0). Each bio-reactor was inoculated with $200 \mathrm{~mL}$ of Fungal Biomass. The process was evaluated during 5 days at $20^{\circ} \mathrm{C}$, airflow of $1 \mathrm{~L} / \mathrm{min}$ and $\mathrm{pH} 6.5$.

Bacterial suspensions of $5 \mathrm{~mL}$ were prepared in saline solution $(0.85 \% \mathrm{w} / \mathrm{v})$. The bacteria concentration in each suspension was $10 \times 10^{8}$ cells $/ \mathrm{mL}$. These 4 suspensions were mixed in equal proportion (1:1:1:1). Purity and viability of inoculum were verified using Gram staining, and culturing serial dilutions in $\mathrm{Nu}-$ tritive agar.

The fungal/bacterial consortia were prepared by mixing $333 \mathrm{~mL}$ (fungal bio- 
mass forming pellets) of each fungus, $P$. ostreatus. T. versicolor and Trametes $\mathrm{sp}$, and then these suspensions were mixed with $1.7 \mathrm{~mL}$ of bacterial inoculum using a sterile food processor. The inoculum was stored at $4{ }^{\circ} \mathrm{C}$ until its final inoculation $(10 \% \mathrm{v} / \mathrm{v})$ in the extended aeration bioreactor of $15 \mathrm{~L}$ capacity. The Biological activity and viability of the consortia were evaluated during the experiment by plating in PDA agar (Fungi) and Nutritive Agar (Bacteria). The monitored enzymes were Laccase [29], Mn Peroxidase [30] and Lignin Peroxidase [31].

\subsection{Wastewater Ampling and Characterization}

This study used two types of wastewater. The first type was named as Biological staining waste water (BSWW) and was obtained from laboratories in a Faculty of Sciences. The BSWW was produced during cell staining procedures perform in laboratories of research and teaching laboratories. Samples were taken from 7 laboratories and then mixed in order to obtain a composite sample. The second type of water was domestic wastewater (DWW). These samples were obtained from a septic distribution box for domestic wastewater. Both types of water were characterized in terms of Chemical Oxygen Demand COD (5210B Method) [32], Biochemical Oxygen Demand $\left(\mathrm{BOD}_{5}\right)$ [32], Color Units (CU) [33], pH, conductivity, Total Suspended Solids (TSS) (2540 D Method) [32], Total Bacterial Count, Total fungi and Thermotolerant coliforms (CFU/mL the results were present with $\log _{10} \mathrm{CFU} / \mathrm{mL}$ ) [34].

\subsection{Removal Experiments Using BSWW and DWW}

\subsubsection{Factorial Design $2^{2}$ with Center Points for the Selection of Wastewater Volume}

An experimental design to evaluate the effect of the BSWW and DWW on COD and color removal was performed (selection of working volume). 4 treatments with three center points were established. The evaluated factors and their respective levels are shown in Table 1 . The experiments were run in $1 \mathrm{~L}$ containers using a working volume of $0.8 \mathrm{~L}$ and an inoculum percentage of $10 \%(\mathrm{v} / \mathrm{v})$. The aeration rate was $1 \mathrm{~L} / \mathrm{min}$ and the temperature was maintained at $20^{\circ} \mathrm{C}$. COD and $\mathrm{CU}$ were selected as response variables. An ANOVA Test was used to determine a significant effect of the evaluated factors using statistical software Design Expert 7.0. Significant differences between treatments were established by mean comparison tests using SAS 9.0 [27] [34].

\subsubsection{Step Descent Optimization}

Step descent optimization was used to determine the minimum volume of DWW required for supplementing the BSWW and performed the co-treatment. The best treatment from the factorial design $2^{2}$ was selected as the center point (rate 3:1 of BSWW and DWW). Three descent steps were calculated (Descent 1: ratio 3.5:0.5, descent 2: ratio 3.9:0.1 and descent 3: ratio 4.0:0). This experimental design had a total of 4 treatments evaluated in triplicate in $1 \mathrm{~L}$ bio-reactors. The experiments were performed in the same conditions as those used during the 
Table 1. Factorial Design $2^{2}$ with two center points to select the volumes of wastewater to be dosed as co treatment.

\begin{tabular}{ccc}
\hline Treatments & $\begin{array}{c}\text { Factor } \mathrm{X}_{1} \\
\text { BSWW }\end{array}$ & $\begin{array}{c}\text { Factor } \mathrm{X}_{2} \\
\text { DWW }\end{array}$ \\
\hline 1 & -1 & -1 \\
2 & 1 & -1 \\
3 & -1 & 1 \\
4 & 1 & 1 \\
PC & $2 \mathrm{~L}$ & $2 \mathrm{~L}$ \\
Factor $\mathrm{X}_{1}$ & -1 & +1 \\
BSWW & $1 \mathrm{~L}$ & $3 \mathrm{~L}$ \\
Factor $\mathrm{X}_{2}$ & -1 & +1 \\
DWW & $1 \mathrm{~L}$ & $3 \mathrm{~L}$ \\
\hline
\end{tabular}

factorial design. An ANOVA Test was used to determine a significant effect of the evaluated factors using statistical software Design Expert 7.0. A comparison of means between treatments was made after 48 hours of treatment (Tukey test alpha value of 0.05 , SAS 9.0 for Windows).

\subsubsection{Pilot Plant Evaluation}

The pilot treatment plant (Figure 1) consisted of a homogenization, neutralization and mixing tank of $130 \mathrm{~L}$. Then a fat trap of $8 \mathrm{~L}$ was installed. This unit included and hydraulic baffle that improved the removal efficiency. The retention time in this tank was $2 \mathrm{~min}$. Following this unit, an extended aeration Bio-reactor (Turbulent flux and dissolve oxygen higher than $1 \mathrm{mg} / \mathrm{L})$ of $15 \mathrm{~L}(10 \mathrm{~L}$ of working volume) was installed. This reactor was inoculated with $10 \%(\mathrm{v} / \mathrm{v})$ of Fungal/Bacterial consortia and the hydraulic retention time was $48 \mathrm{~h}$. The sludge produced by the bioreactor was recovered by a sludge decanter of $15 \mathrm{~L}$ capacity. The retention time for this unit was $30 \mathrm{~min}$. Finally, the system was connected to two filtration units with retention times of 2 minutes. The filtration material was quartz sand and activated carbon (ratio 1:1). In order to extend the usable life of the filtration units and avoid silting of the filtration material a washing valve was installed.

The treatment plant was evaluated during 3 consecutive cycles of 49 hours up to a total of $147 \mathrm{~h}$. Samples were taken at the time $0,24 \mathrm{~h}$ and $48 \mathrm{~h}$, in each cycle in order determine the following parameters $\mathrm{COD}, \mathrm{BOD}_{5}, \mathrm{SST}, \mathrm{pH}$, dissolved oxygen, total fungus count, total bacterial count and enzymatic activity (Laccase, $\mathrm{MnP}$ and $\mathrm{LiP}$ ). In order to evaluate changes in the UV-Vis absorption spectra due to modification of the absorber species, UV/Vis spectra $(200-800 \mathrm{~nm})$ were determined for the sample pre and post-treatment to evaluate changes in absorption spectra of colored compounds in the sample.

\subsubsection{Greenhouse Re-Use Test}

The effluent obtained after each cycle of treatment was characterized in order to 


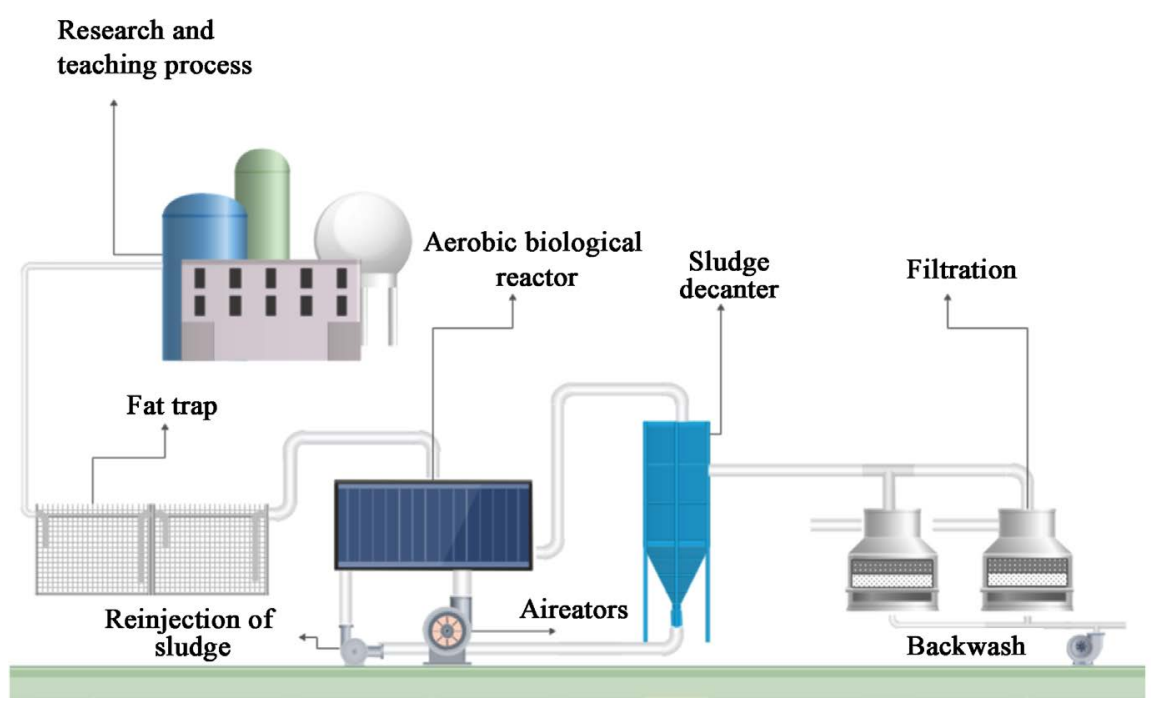

Figure 1. Schematics of Pilot Plant. The Pilot Plant is composed of an initial mixing tank, fat trap, aerobic biological reactor, sludge decanter and sand filter.

establish its quality for being used as irrigation water. The grass was selected as a biologic model for greenhouse tests. A Factorial experiment with a completely randomized design was applied. The different factors were irrigation water, soil type and the mixing ratio. The effluent obtained from each treatment cycle was tested, cycle 1 (TEC1), cycle 2 (TEC2) and cycle 3 (TEC3) and also untreated wastewater. As control drinking water was evaluated (DWW). Two types of soil in combination with quartz sand were assessed (greenhouse soil-GHS and Garden soil-GS). The different combinations were as follows: $100 \%$ soil, $50 \%$ soil $50 \%$ Quartz sand and 25\% soil 75\% quartz sand. The different combinations were sterilized $\left(121^{\circ} \mathrm{C}, 15\right.$ Psi during $\left.15 \mathrm{~min}\right) .3$ sterilization cycles were applied, $24 \mathrm{~h}$ between each cycle. The plants were growth in triplicate in plastic containers of $100 \mathrm{~mL}$ with $50 \mathrm{~g}$ of the mixture. $0.4 \mathrm{~g}$ of Lolium perenne seeds were culture per container. Plants were watered two times per week and after 60 days response variables were analyzed.

The response variable was RDW (Root Dry Weight) [35]. The Analysis of variances was performed using $\mathrm{R}$ statistical software in $\mathrm{R}$ wizard platform [36]. Additionally, the following parameters were also tested, the concentration of Total Phosphorus (TP), Available phosphorus (AP), Phosphorus extracted from Water (PEW), Total Nitrogen, nitrates, Ammonium, $\mathrm{pH}$ and conductivity (C) [37] [38] [39].

\section{Results and Discussion}

\subsection{Wastewater Characterization}

The results of the initial characterization of BSWW are shown in Table 2. Different factors such as the high value of $\mathrm{COD}$ and $\mathrm{BOD}_{5}$, grease, color, and the low treatability ratio of $\mathrm{BOD}_{5} / \mathrm{COD}$, less than 0.5 make of this residue especially 
Table 2. Wastewater characterization before treatment.

\begin{tabular}{|c|c|c|c|c|c|c|}
\hline Parameter & Units & BSWW & DWW & $\begin{array}{c}\text { Mixture } 3.5: \\
0.5 \text { cycle } 1\end{array}$ & $\begin{array}{c}\text { Mixture } 3.5: \\
0.5 \text { cycle } 2\end{array}$ & $\begin{array}{c}\text { Mixture } 3.5 \\
0.5 \text { cycle } 3\end{array}$ \\
\hline $\mathrm{pH}$ & & 7.07 & 8.16 & 7 & 7 & 7 \\
\hline Color & UC & 3409 & 36 & 1367 & 1053 & 1027 \\
\hline Greases and oil & $\mathrm{mg} / \mathrm{L}$ & 426 & ND & ND & ND & ND \\
\hline TSS & $\mathrm{mg} / \mathrm{L}$ & 170 & 112 & 566 & 67 & 200 \\
\hline Nitrates & $\mathrm{mg} / \mathrm{L}$ & 0.1 & $<0.01$ & 0.03 & 0.03 & 0.03 \\
\hline Nitrites & $\mathrm{mg} / \mathrm{L}$ & 0.001 & $<0.001$ & 0.001 & 0.001 & 0.001 \\
\hline Orthophosphate & $\mathrm{mg} / \mathrm{L}$ & 29.21 & 52.45 & 26.61 & 26.5 & 26.23 \\
\hline Sulfate & $\mathrm{mg} / \mathrm{L}$ & 410 & 510 & 440 & 440 & 440 \\
\hline COD & $\mathrm{mg} / \mathrm{L}$ & 6960 & 135 & 6855 & 5400 & 5100 \\
\hline $\mathrm{BOD}_{5}$ & $\mathrm{mg} / \mathrm{L}$ & 1500 & 106 & 2005 & 1790 & 1550 \\
\hline $\begin{array}{c}\text { Ratio } \\
\mathrm{BOD}_{5} / \mathrm{COD}\end{array}$ & NA & 0.21 & 0.78 & 0.3 & 0.33 & 0.31 \\
\hline TOC & $\mathrm{mg} / \mathrm{L}$ & 480 & 120 & 240 & 240 & 240 \\
\hline Total bacteria & $\begin{array}{c}\log _{10} \\
\mathrm{CFU} / \mathrm{mL}\end{array}$ & 5.0 & 6.0 & 7.0 & 7.0 & 7.0 \\
\hline Total fungus & $\begin{array}{c}\log _{10} \\
\mathrm{CFU} / \mathrm{mL}\end{array}$ & $<2$ & $<2$ & 5.0 & 6.0 & 4.0 \\
\hline $\begin{array}{c}\text { Thermotolerant } \\
\text { coliforms }\end{array}$ & $\begin{array}{c}\log _{10} \\
\mathrm{CFU} / \mathrm{mL}\end{array}$ & $<2$ & 3.0 & 5.4 & 5.2 & 5.3 \\
\hline
\end{tabular}

difficult to treat. These particularly elevated values might be related to the presence of dyes, solvents and mordants. In contrast, DWW evaluation had greater treatability value $>0.5$ in comparison to BSWW and lower values of the aforementioned parameters. This would be associated with its type and domestic origin. Related with microbiological analyses on Biological-staining wastewater (BSWW) were recovery total bacteria only with 5.0 logarithmic units, while for the domestic wastewater (DWW) total bacteria and thermotolerant coliform counts were 6.0 and 3.0 logarithmic units respectively (Table 2).

After increasing the value of treatability found in BSWW (0.21) by mixing with DWW, it would be possible to improve its co-treatment using Fungal/Bacterial consortia. The results found after the initial characterization of wastewater were similar to those reported by Fernandez et al. 2016 and Garcia et al. 2017 [6] [7]. Both authors found elevated values of COD and color that affected the treatability of BSWW using advanced oxidation technologies (Photocatalysis with $\mathrm{TiO}_{2}$, Fenton and photo-Fenton). A similar effect would be expected after using a biological treatment since microorganisms can be harmed by the high concentration of pollutants that could cause a toxic environment for them. 
For the above-mentioned reason, this study evaluated the most appropriate mixing rate of BSWW and DWW to make possible the co-treatment in aerobic and mesophilic conditions using heterotrophic fungi and bacteria adapted to BSWW.

\subsection{Factorial Design $2^{2}$ with 3 Center Points}

The results of the ANOVA suggest that the models were significant in terms of COD and color removal since high regression coefficients were found $(0.98$ and 0.95). Moreover, the model showed a great precision with a value $>4.0$. The most important factor for both response variables was DWW $\left(\mathrm{X}_{2}\right)$ with $\mathrm{p}$ values of 0.0039 and 0.0101 for COD and CU respectively. For this factor the regression coefficients were -90.5 and -27.5 , indicating that should be evaluated in its lower level (1 L DWW). Optimization studies could reduce more this value (Table 3).

Additionally, significant differences between treatments were found for the parameters COD and CU. Concerning COD, the best treatment was T3 (BSWW and DWW 1:3) followed by T1, T2 and T4. The final COD values were 794 $\mathrm{mg} / \mathrm{L}, 882 \mathrm{mg} / \mathrm{L}, 624 \mathrm{mg} / \mathrm{L}$ and $690 \mathrm{mg} / \mathrm{L}$ for treatments T1, T2, T3 and T4 respectively (Figure 2(a)). In terms of color removal, treatments T2, T3 and T4 did not show significant differences ( $p>0.0001)$ ( $>200$ UC after $48 \mathrm{~h}$ ). The selected treatment for the following experiments corresponded to T2 (3:1 BSWW/ DWW), due to the volumes of BSWW that can be treated and the reduction of the costs related to the final disposition of the liquid residues.

The reason why the DWW could improve the level of biodegradability of BSWW $(0.31 \pm 0.04)$ is related with the presence of more easily degradable

Table 3. Analysis of variances factorial design $2^{2}$ with 3 center points and regression analysis.

\begin{tabular}{|c|c|c|c|c|c|c|c|c|c|c|c|}
\hline \multicolumn{7}{|c|}{ COD } & \multirow{2}{*}{\multicolumn{5}{|c|}{$\begin{array}{c}\text { Color units } \\
\mathrm{CU}\end{array}$}} \\
\hline \multirow[t]{2}{*}{ Factor } & \multicolumn{6}{|c|}{$(\mathrm{mg} / \mathrm{L})$} & & & & & \\
\hline & SS & $\mathrm{DF}$ & MS & F-value & Test $>\mathrm{f}$ & $\mathrm{RC}$ & SS & $\mathrm{DF}$ & MS & F-value & e Test $>\mathrm{f}$ RC \\
\hline Model & 38822 & 3 & 12941 & 101.3 & 0.0098 & 748 & 3755 & 3 & 1252 & 40.38 & $0.0243 \quad 211$ \\
\hline $\mathrm{X}_{1}$ & 5929 & 1 & 5929 & 46.41 & 0.0209 & 38.5 & 441 & 1 & 441 & 14.23 & $0.0637 \quad 1$ \\
\hline $\mathrm{X}_{2}$ & 32761 & 1 & 32761 & 256.45 & 0.0039 & -90.5 & 3025 & 1 & 3025 & 97.58 & $0.0101-27.5$ \\
\hline $\mathrm{X}_{1} \mathrm{X}_{2}$ & 132.2 & 1 & 132 & 1.04 & 0.416 & 1 & 289 & 1 & 289 & 9.32 & $0.0926 \quad 1$ \\
\hline Pure Error & 255 & 1 & 127 & 4.97 & 0.1555 & & 1701 & 1 & 31 & & \\
\hline $\begin{array}{c}\text { Total } \\
\text { Correlation }\end{array}$ & 39713 & 6 & & & & & 5518 & 6 & & & \\
\hline $\mathrm{R}^{2}$ & & 0.98 & & & & & $\mathrm{R}^{2}$ & & 0.95 & & \\
\hline $\begin{array}{c}\text { Adq. } \\
\text { Precision }\end{array}$ & & 27 & & & & & $\begin{array}{c}\text { Adq. } \\
\text { Precision }\end{array}$ & & 16.5 & & \\
\hline
\end{tabular}

In bold type, the significance of the model and the factors that were significant within the model are highlighted. 


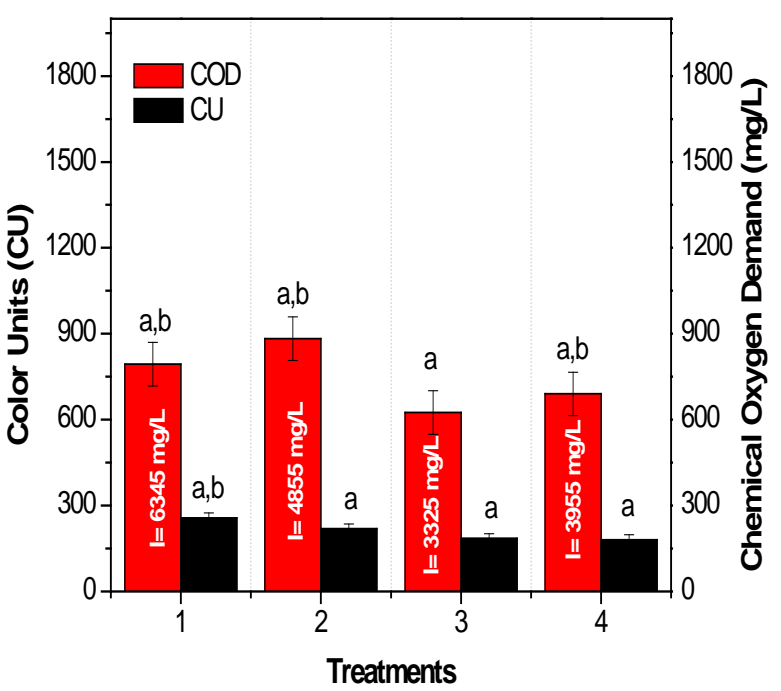

(a)

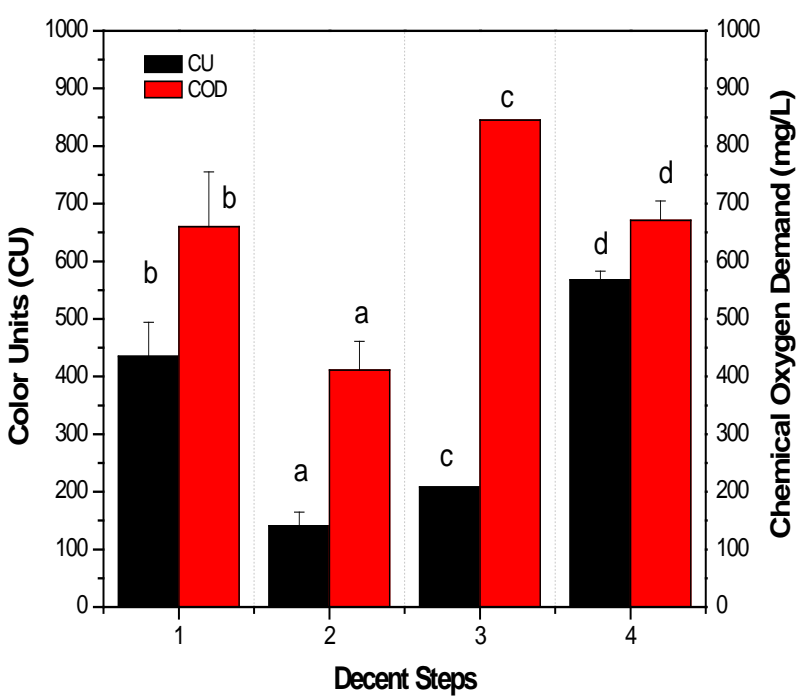

(b)

Figure 2. (a) Evaluated treatments in Plackett-Burman Experimental Design (PBED). (b) Mean comparison among treatments from Path of step descent experiment experimental design; the letters a, b, c and d represent the homogeneous groups obtained with the Tukey assay where letter a belongs to the treatments with lower COD and CU

forms of carbon, nitrogen and organic phosphorus if compare with those found in dyes and solvents [24] [40]. Under these conditions, the Fungal/Bacterial consortia could obtain nutrients faster in order to support the primary metabolism. During this time dyes might be adsorbed to the cell wall surface and then bio-transformed by the action of extracellular enzymes [41].

\subsection{Step Descent Optimization}

The results obtained during the Factorial design $2^{2}$ indicated that factor $\mathrm{X}_{2}$ had negative regression coefficients in terms of COD and color (-90.5 and -27.5). This suggests that DWW volume can be reduced even more to optimize the re- 
moval. The results attained from center points (ratio 3:1) were similar to those found in factorial experiment $2^{2}$. This indicates that under the same operational conditions the experiment is reproducible. In regards to the step descent experiment, significant differences were found between treatments $(\mathrm{p}<0.0001)$. The descent number 1 (ratio of 3.5:0.5) showed the lowest values of COD concentration $(400 \mathrm{mg} / \mathrm{L})$ and color units $(130 \mathrm{CU})$ (Figure 2(b)) in comparison with descent 2 and 3 . This could imply that DWW is required and even at lower concentrations its presence could influence the performance of the consortia.

In order to increase biodegradability of BSWW, this was supplemented or adjusted by combining with DWW (ratio, 3.5:0.5). DWW was responsible for providing organic matter and nutrients that might be easily taken by Fungal/Bacterial consortia (Table 2). Preliminary tests carried out by the research group showed that fungi and bacteria used in this study were capable of produce cellulases, hemicellulases, lipases and proteases (Data not showed). These results indicate that consortia was capable of use DWW as substrate and thus favor the co-treatment of the chemically more complex BSWW.

\subsection{Pilot Plant Experiments}

The wastewater was characterized and results are shown in Table 2. This initial characterization was used in the experiments at pilot plant scale (3.5:0:5 BSWW/DWW). By mixing these two types of wastewater it was possible to adjust the initial concentration of the majority of the evaluated parameters. The concentration of pollutants present in the modified wastewater might improve its biological treatment by increasing its index of treatability from 0.21 (BSWW) to 0.1 (BSWW/DWW). Additionally, it lowers color units and provides an easy source of carbon/nitrogen. Instead, when both types of wastewater were mixed microbiological counts change and total bacteria start with 7.0 logarithmic units, thermotolerant coliform fluctuate between 5.2 and 5.4 logarithmic units and total fungi were between 4.0 and 6.0 logarithmic units.

The first unitary operation was performed in the fat trap; this corresponded to the liquid-liquid separation of immersion oil. The efficiency obtained during this process was $90 \%(41 \mathrm{mg} / \mathrm{L})$ after 2 min of operation. Remove this contaminant before feeding the biological unit is certainly important due to the formation of films that can hinder the contact of the biomass with the wastewater and also affect oxygen transfer. Once the immersion oil was removed, wastewater was transferred to the extended aeration bio-reactor. In this unit, the color removal increased as a function of time during Cycle 1. The wastewater obtained from the output filters after 49 hours present $80 \mathrm{CU}$ (Figure 3(a)).

Discoloration during cycle 1 was higher than cycle 2 and 3 . Significant differences between cycles were found $(\mathrm{p}<0.0001)$. This can be related to dye removal caused by biomass adsorption. Cycles 2 and 3 showed $\mathrm{CU}$ equivalent to 121 and $106 \mathrm{CU}$ after 99 and $149 \mathrm{~h}$ respectively. Following each cycle, biomass surface became saturated, and therefore the removal efficiency decreased. Despite having 


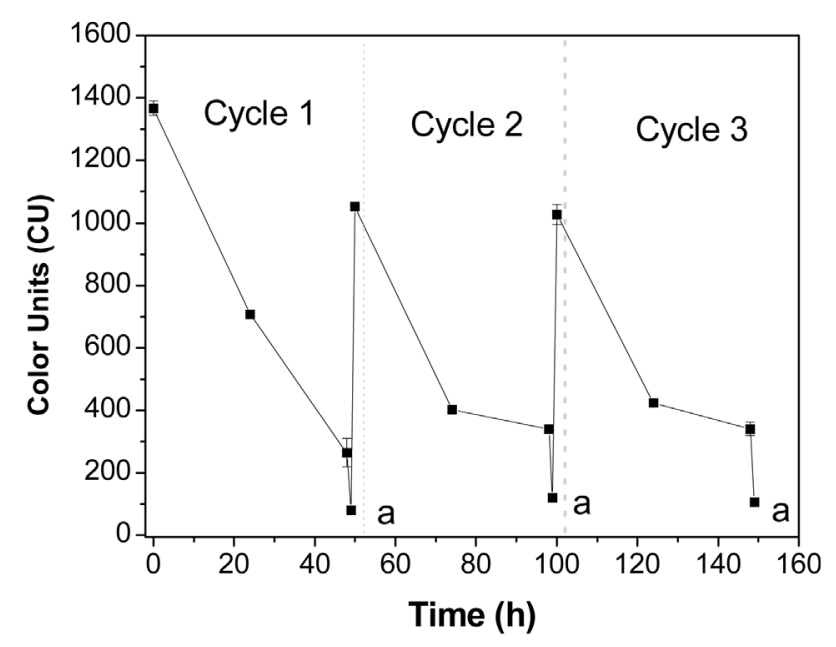

(a)

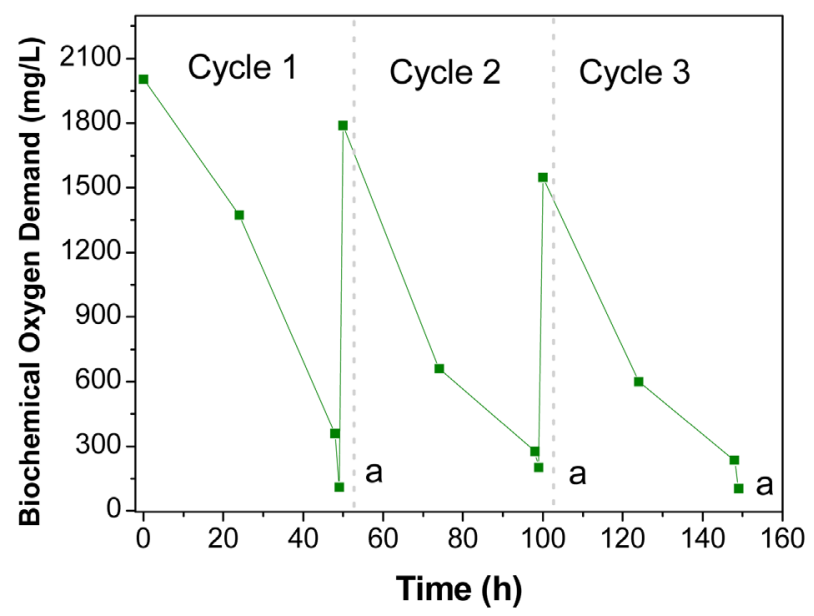

(c)

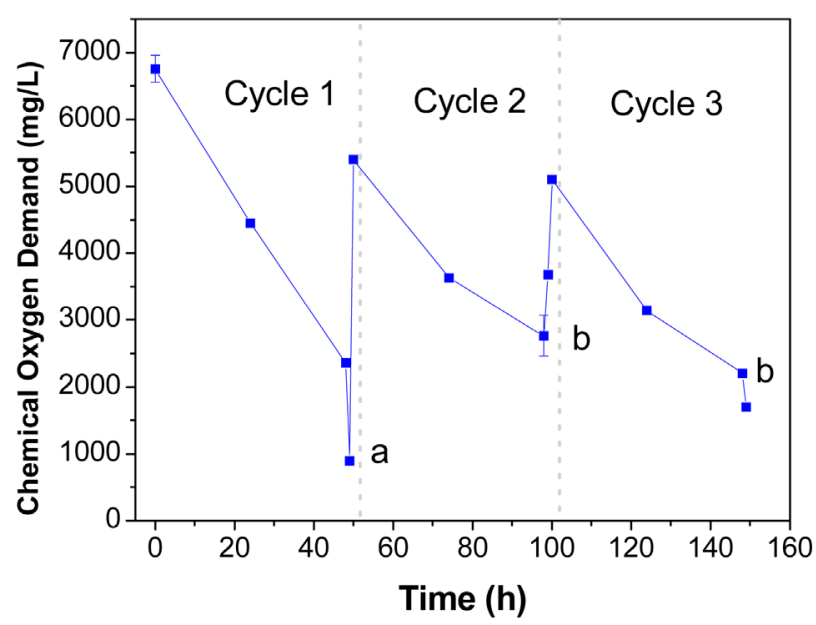

(b)

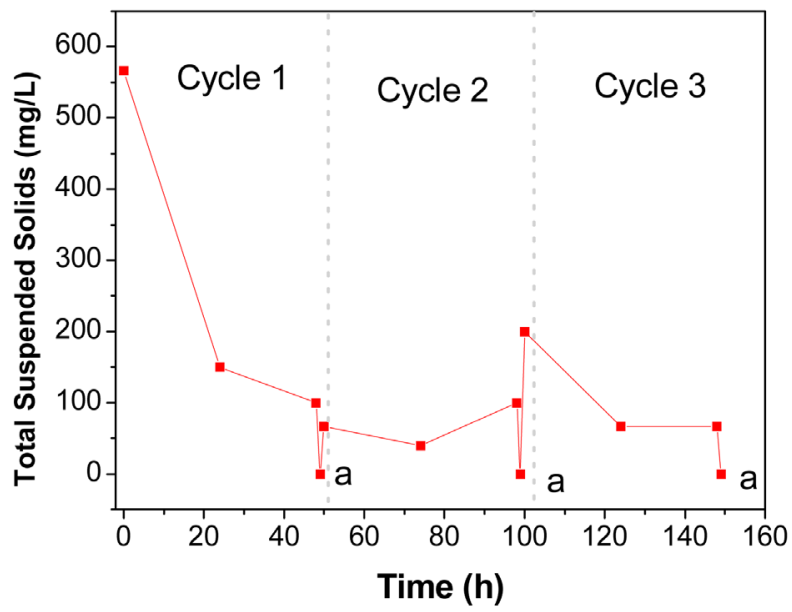

(d)

Figure 3. Removal efficiencies in the pilot plant for 3 cycles of operation. (a) Color units; (b) Chemical oxygen demand; (c) Oxygen biochemistry demand; (d) Total suspended solids. The letters a and b represent the homogeneous groups obtained with the Tukey assay where letter a belongs to the treatments with lower COD and CU.

this level of variability between cycles, it is certain that fungal/bacterial consortia was capable of removing color during the 3 consecutive cycles, since the final values of color were less than $1000 \mathrm{CU}$ (Figure 4(b)). This result is important considering that Colombian law requires a maximum value of $1000 \mathrm{CU}$ in wastewater before disposal in the sewage system of Bogota [9]. The resolution that applies for Colombia, does not have the values for color units allowed, only the absorbances $436 \mathrm{~nm}, 525 \mathrm{~nm}$ and $620 \mathrm{~nm}$ are reported. Results show absorbances after filtration from $0.118,0.074,0.0055$ to $436 \mathrm{~nm}, 525 \mathrm{~nm}$ and $620 \mathrm{~nm}$. Data demonstrate lower results than at the beginning, due to remotion based on adsorption and biotransformation especially at $525 \mathrm{~nm}$ and $620 \mathrm{~nm}$ (Figure 5).

Concerning the mechanisms involved in the color removal, it is well known that bacterial and fungal wall contain certain polysaccharides considered as polyelectrolytes formed by quitine and peptidoglycan [42]. These polyelectrolytes 


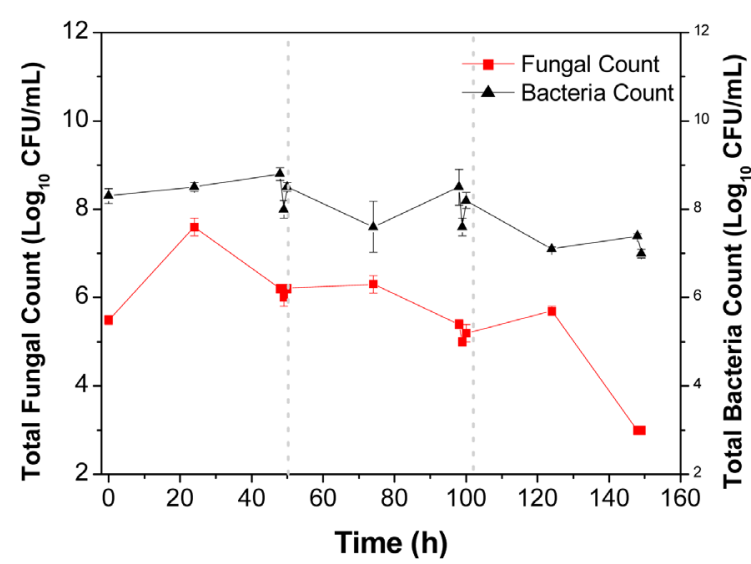

(a)

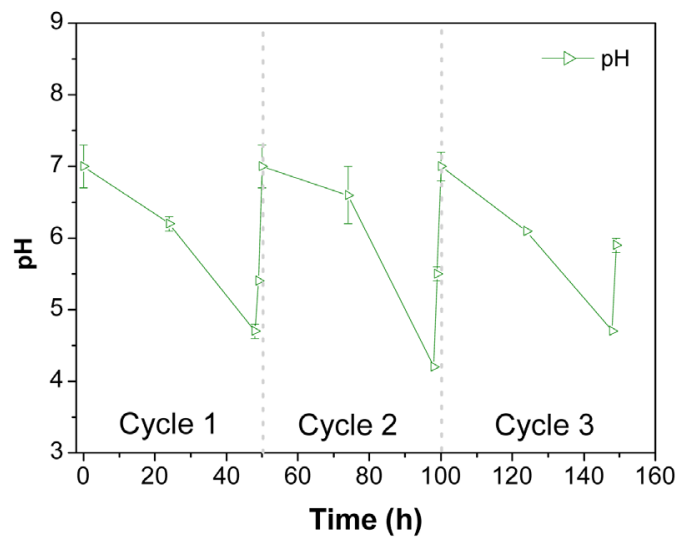

(c)

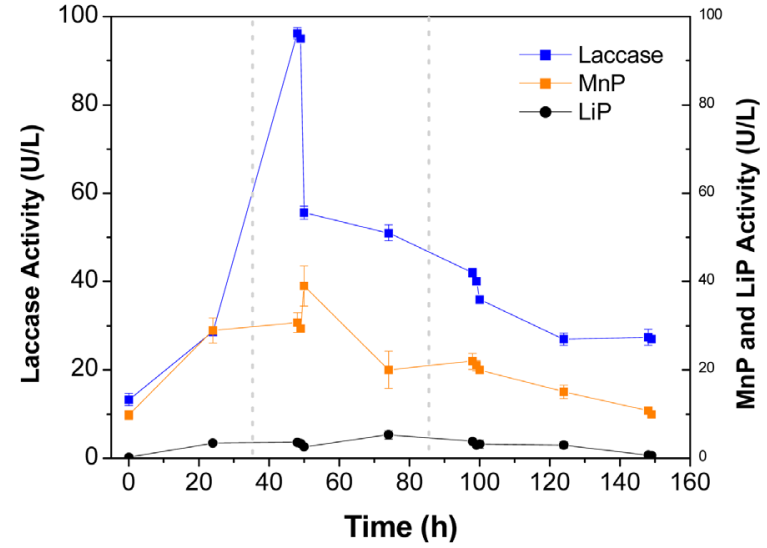

(b)

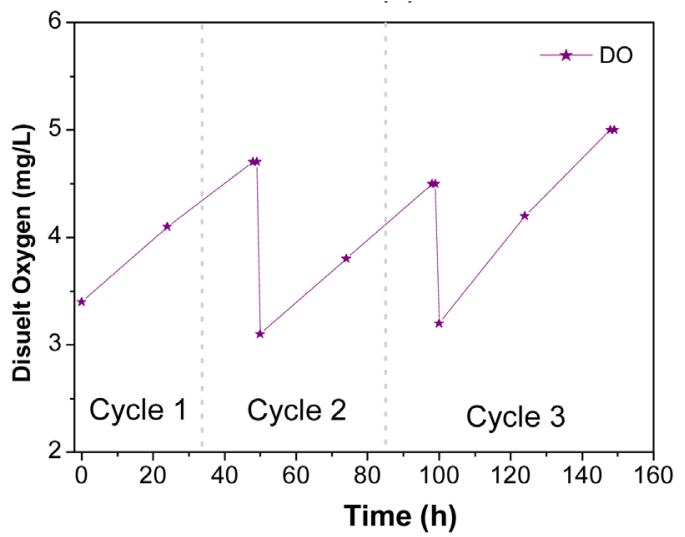

(d)

Figure 4. Counting of fungi, bacteria and enzymatic activities, in the treatment plant for 3 cycles of operation. (a) Fungal and total bacteria count; (b) Enzymaticactivities laccase, MnP and LiP; (c) pH and (d) Dissolved oxygen.

may act as adsorbents due to physic-chemical process that takes place in the solid-liquid interphase [43] [44]. The dyes present in the wastewater possess a cationic nature and therefore under an acidic environment (4.0 - 6.0) tend to be easily absorbed.

The $\mathrm{pH}$ values registered during the process in the bioreactor (Figure 5(c)) decreased gradually from 7.0 to 5.8. This value was below the $\mathrm{pK}$ for this type of dyes (6.9 and 8.6). As a result of this trend, the biomass surface was not charged. It is possible that adsorption during the first hours of treatment was related to weak bonds such as hydrogen bonds and Van der Waals interactions [27].

In relation to COD response to operational time and cycles, it was determined that initial concentrations were $6755 \mathrm{mg} / \mathrm{L}, 5400 \mathrm{mg} / \mathrm{L}$ and $5100 \mathrm{mg} / \mathrm{L}$, for cycle 1, 2 and 3 respectively. Biological treatment reduced the COD concentration after each operational cycle. This was evidenced after secondary sedimentation and in the output of sand and activated carbon filters (Figure 3(b). As well as color, COD removal was statistically different in each operational cycle $(\mathrm{p}<$ 0.0001 ) due to the saturation of active sites and formation of by-products derived from bio-transformation [44] [45]. 


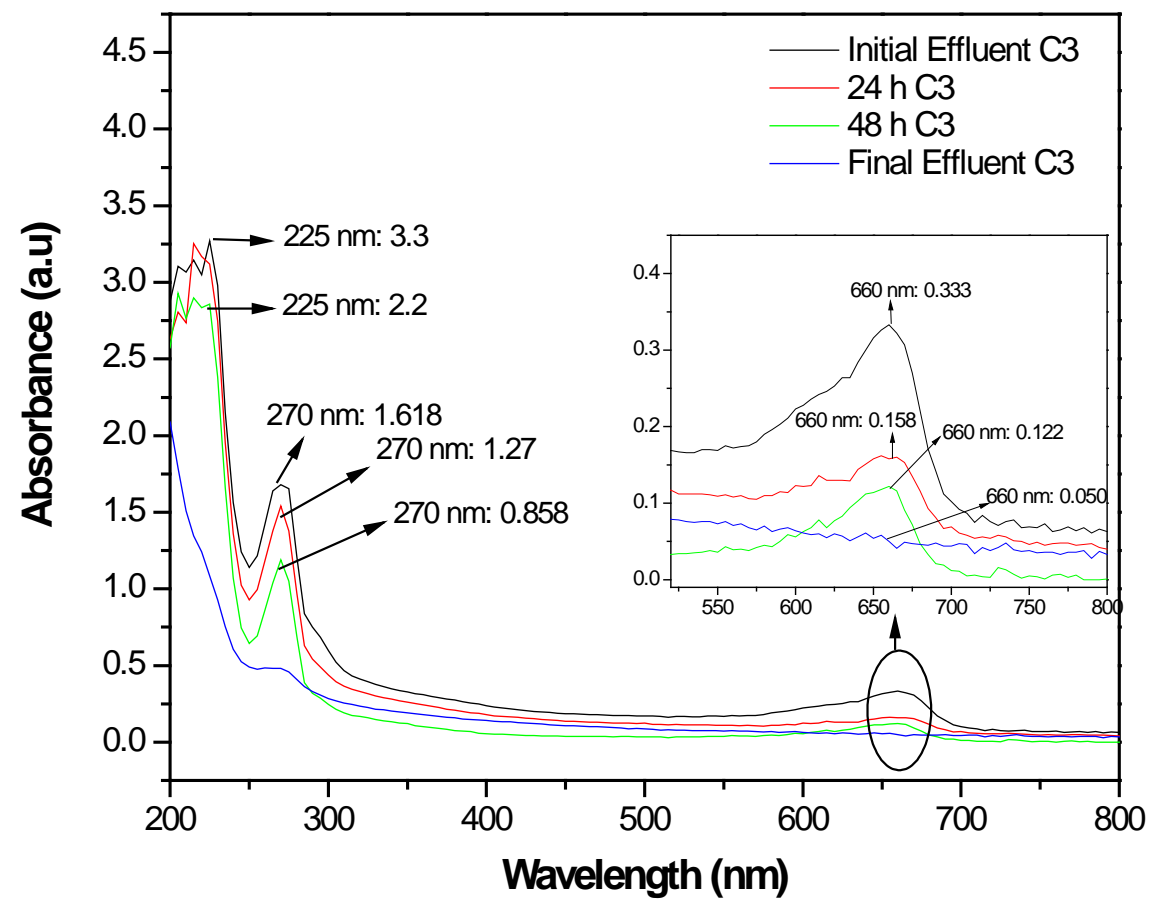

(a)

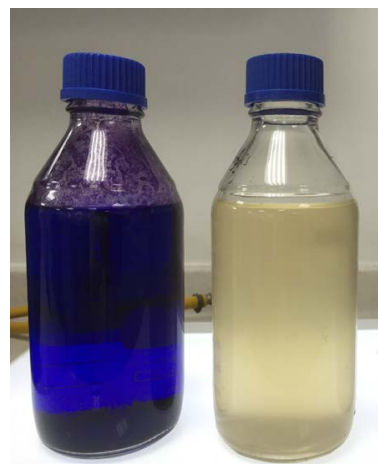

(b)
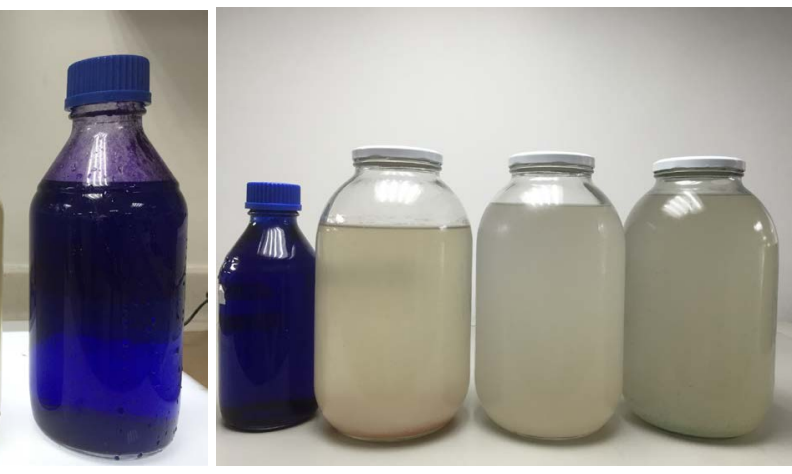

(c)

Figure 5. (a) UV/VIS spectral curves for initial wastewater and final effluent in cycle 3; (b) Color of initial BSWW, DWW and 3.5:0.5 of BSWW/DWW; (c) Final color of wastewater for cycle 1,2 and 3.

Another significant factor evaluated was $\mathrm{DBO}_{5}$. It was observed that initial concentrations were $2005 \mathrm{mg} / \mathrm{L}, 1790 \mathrm{mg} / \mathrm{L}$ and $1550 \mathrm{mg} / \mathrm{L}$, lower values in comparison with COD due to wastewater characteristics. After analyzing the results obtained after each operative cycle, it was noticed a higher efficiency if compare with COD. The $\mathrm{BOD}_{5}$ values were $110 \mathrm{mg} / \mathrm{L}, 115 \mathrm{mg} / \mathrm{L}$ and $105 \mathrm{mg} / \mathrm{L}$ for cycle 1,2 y 3 respectively ( $p>0.0001$ ) (Figure $4(c)$ ). The treatment plant proved to be effectively operating as a sequential system. Additionally, the evaluated parameters were below the maximum limits established by Colombian law for wastewater disposal at Bogotá city (COD: $1500 \mathrm{mg} / \mathrm{L}, \mathrm{BOD}_{5} 800 \mathrm{mg} / \mathrm{L}$ ) [9]. However, $\mathrm{DQO}$ and $\mathrm{BOD}_{5}$ did not decrease enough to accomplish into limits of resolution 0631 from 2015 [8]. So its important at future made some mod- 
ifications to the wastewater pilot plant to increase remotion efficiency. Even so, results were important due to remotion was higher than $90 \%$ with complexity of wastewater evaluated. TSS was another important parameter that helps to show the efficiency of the system since values were lower than $0.001 \mathrm{mg} / \mathrm{L}$ in each treatment cycle after filtration.

The increase in Fungi and Bacteria concentration due to biotransformation and consumption of organic matter present in wastewater was also tested during pilot plant processing (Figure 4(a)). At the beginning of the biological treatment, the microbial concentration was 5.5 and $8.3 \log _{10} \mathrm{UFC} / \mathrm{mL}$ for Fungi and bacteria respectively. During the entire process fungal concentration was lower (3.0 - 7.6 $\left.\log _{10} \mathrm{UFC} / \mathrm{mL}\right)$ than bacteria $\left(7.0-8.8 \log _{10} \mathrm{UFC} / \mathrm{mL}\right)$. The differences between the total counts of the two microorganisms that form the inoculum are explained by the presence of fewer complex by-products released by the fungi. Bacteria can use these compounds along with the biodegradable organic matter found in DWW to growth at a faster rate than fungi. The counts for thermotolerant coliform decreased between cycles showing 4.4, 4.2 and 4.1 logarithmic units for cycle 1, 2 and 3. Despite implementing operations and physical and biological unit process, the pilot wastewater treatment plant does not eliminate the total of thermotolerant coliform, so a complementary process as UV disinfection, photocatalysis or chlorination is necessary to eliminate this type of microorganisms.

Hernández et al. 2017 [46] evaluated the growth of two types of white rot fungi and five aerobic bacteria in presence of different dyes. They showed that microbial growth can be achieved in synthetic wastewater by the addition of chemically defined compounds such as glucose, ammonium chloride, copper sulfate and copper manganese. Moreover, removal of color and COD was higher than $80 \%$ after $48 \mathrm{~h}$ of treatment, using $1 \mathrm{~L}$ bioreactors during a single operation cycle. In contrast to Hernández et al. 2017 [46], in the present study three operational cycles were evaluated. It is possible that operational cycles triggered microbial mechanisms of adaptation due to the presence of wastewater compounds. Because of this, bacteria recovered from the last operational cycle would be more adapted to wastewater conditions than those introduced at beginning of the treatment.

The enzymatic activities are presented in Figure 4(b). Highest activities, 96 $\mathrm{U} / \mathrm{L}$ and $39 \mathrm{U} / \mathrm{L}$ for laccase and $\mathrm{MnP}$ were observed during cycle 1 . Then the enzymatic activity decrease. During cycle 3 the following values were obtained, $27 \mathrm{U} / \mathrm{L}$ of Laccase and $10 \mathrm{U} / \mathrm{L}$ of MnP. Moreover, these two enzymes were related to $\mathrm{COD}, \mathrm{BOD}_{5}$ and color removal, during the entire treatment. LiP activity was low during the 3 cycles. It is likely that this enzyme is not directly related to chromophores modification but action on aromatic rings and aliphatic by-products.

Although enzymatic activity did not disappear completely, it was probably reduced due to the action of extracellular proteolytic enzymes released by the 
consortia itself or by the natural microflora present in the DWW. As it was mentioned before fungi and bacteria produce unspecific proteases that can hydrolyze peptide bonds. The ligninolytic enzymes are catalytic proteins, thus, they could have been hydrolyzed, especially during cycle 3 , since biomass could suffer from aging and saturation processes [47].

The action of ligninolytic enzymes in dyes degradation begins with the Laccases. This group of enzymes performs a successive oxidation of conjugated rings and creating free radicals. These aromatic rings are part of the chromophore structure which is responsible for color. Once the dye is adsorbed to the fungal cell wall discoloration is potentiated by laccase action [2] [27] [44].

Laccase can also demitilize, releasing methyl groups. This effect is commonly observed in dyes such as Crystal violet and Malachite Green. Once the aromatic rings have been modified they can be oxidized or passing through a process of decarboxylation. Finally, aliphatic by-products of three carbons are formed and these can be metabolized via tricarboxylic acid cycle. During this last step, different isoforms of laccase and peroxidase can act [41] [48].

$\mathrm{UV} / \mathrm{Vis}$ scanning test of the untreated wastewater showed a maximum absorption signal in the visible region at $660 \mathrm{~nm}$ (Figure 5). This signal reduced their intensity along the treatment until reached 0.05 Absorbance Units (AU) once out of the filters. The signal reduction was caused by the combined action of bio-adsorption during the early period of contact and enzymatic biotransformation. Moreover, the system of filters potentiates the removal due to the great contact surface that possesses the materials used for filtration such as activated carbon and sands [49] [50].

Other signals were found in ultraviolet region. These were found at $270 \mathrm{~nm}$ and $225 \mathrm{~nm}$ and were associated with the aromatic rings that form the chemical structure of certain dyes and alcohols. The intensity of these signals also decreased during the treatment (three cycles), indicating that the aromatic rings were oxidized by the enzymes and also adsorbed to the filtration units.

\subsection{Reuse of Post-Treated Water in Irrigation Tests}

In order to test the post-treated water in the irrigation tests of Lolium perenne at Greenhouse scale, this was characterized in terms of its physicochemical and microbiological characteristics. This test will help to determine in the future this type of wastewater can be used irrigation systems of garden and non-urban areas like in the green areas of faculty campus where the experiments took place.

The untreated wastewater has a moderate level of salinity and sodium content. This possesses a moderate risk of salinization in soils with clayey texture. Clay soils have high capacity for cationic interchange and inadequate drainage conditions. It is recommended to use this type of water in soils with thick or organic structure that are more permeable and plants that can tolerate high concentration of sodium and salts. However, BSWW cannot be applied directly to the soil due to the presence of dyes solvents, mordants and microorganisms. The water 
obtained from cycles 1 and 2 showed a medium level of salinity and low content of sodium. This water can be used in soil with an adequate drainage system and plants with moderate tolerance to salts. Water form cycle 3 has high salinity and should not be used in soils with inadequate drainage system. For this type of water, a special control of salinity could be required even if there is a good drainage system (Table 4).

According to high thermotolerant coliform counts, the wastewater treated cannot be used for the production of food for human or animal consumption.

Table 4. Quality criteria for the use of treated wastewater for agricultural purposes

\begin{tabular}{|c|c|c|c|c|c|}
\hline Parameter & Units & $\begin{array}{l}\text { Outlet } \\
\text { Cycle } 1\end{array}$ & $\begin{array}{l}\text { Outlet } \\
\text { Cycle } 2\end{array}$ & $\begin{array}{c}\text { Outlet } \\
\text { Cycle } 3\end{array}$ & $\begin{array}{c}\text { Maximum admissible } \\
\text { values } \\
\text { (Resolution } 1207 / 2014 \text { ) }\end{array}$ \\
\hline $\mathrm{pH}$ & & 6.9 & 5.9 & 6.1 & $6.0-9.0$ \\
\hline Conductivty & $\mu \mathrm{S} / \mathrm{cm}$ & 613 & 592 & 792 & 1500 \\
\hline RAS & & 8.21 & 10.29 & 10.0 .2 & 5 \\
\hline Color & UC & 80 & 121 & 106 & ND \\
\hline TSS & $\mathrm{mg} / \mathrm{L}$ & $<0.001$ & $<0.001$ & $<0.001$ & 15 \\
\hline COD & $\mathrm{mg} / \mathrm{L}$ & 900 & 3674 & 1695 & ND \\
\hline $\mathrm{BOD}_{5}$ & $\mathrm{mg} / \mathrm{L}$ & 110 & 200 & 105 & ND \\
\hline TOC & $\mathrm{mg} / \mathrm{L}$ & 142 & 72 & 81 & ND \\
\hline Nitrates & $\mathrm{mg} / \mathrm{L}$ & 2.7 & 0.2 & $<0.1$ & 5.0 \\
\hline Nitrites & $\mathrm{mg} / \mathrm{L}$ & 0.024 & 0.001 & 0.001 & $<1.0$ \\
\hline Orthophosphate & $\mathrm{mg} / \mathrm{L}$ & 24.61 & 18.52 & 11.08 & ND \\
\hline \multicolumn{6}{|c|}{ Cations } \\
\hline Calcium & $\mathrm{mg} / \mathrm{L}$ & 15.31 & 16.43 & 23.32 & ND \\
\hline Magnesium & $\mathrm{mg} / \mathrm{L}$ & 3.42 & 3.11 & 4.32 & ND \\
\hline Potasium & $\mathrm{mg} / \mathrm{L}$ & 10.16 & 14.26 & 16.61 & ND \\
\hline Sodium & $\mathrm{mg} / \mathrm{L}$ & 96.51 & 122.71 & 141.90 & 70 \\
\hline Sum of Cationic & $\mathrm{mg} / \mathrm{L}$ & 125.4 & 156.51 & 186.15 & ND \\
\hline \multicolumn{6}{|c|}{ Anions } \\
\hline Sulphates & $\mathrm{mg} / \mathrm{L}$ & 19.53 & 19.07 & 7.12 & 500 \\
\hline Chlorides & $\mathrm{mg} / \mathrm{L}$ & 97.13 & 151.72 & 180.79 & 300 \\
\hline Carbonates & $\mathrm{mg} / \mathrm{L}$ & N.D & N.D & N.D & ND \\
\hline Bicarbonates & $\mathrm{mg} / \mathrm{L}$ & 236.04 & 99.12 & 136.92 & 90 \\
\hline Sum of anions & $\mathrm{mg} / \mathrm{L}$ & 352.7 & 269.91 & 324.83 & ND \\
\hline $\begin{array}{l}\text { Thermotolerant } \\
\text { Coliforms }\end{array}$ & $\begin{array}{c}\log _{10} \\
\mathrm{CFU} / \mathrm{mL}\end{array}$ & 4.4 & 4.2 & 4.1 & $10 \times 10^{4}$ \\
\hline
\end{tabular}


But, the resolution 1207 issue by Ministry of Environment and Sustainable Development in Colombia establishes that they could be used for irrigation of green areas in parks, sport fields and gardens of non-domiciliar areas where the maximum value allow is $1 \times 10^{4} \mathrm{NMP} / 100 \mathrm{~mL}$ or 4.0 logarithmic unit/100 mL for thermotolerant coliform (Table 4).

Figure 6 showed the mean and value distribution between water, soils and dilutions. The results followed a normal distribution: Test Kolmogorov-Smirnov with Lillierfors correction $(\mathrm{p}=0.7345)$ and Shapiro-Wilk $(\mathrm{p}=0.8372)$. Variance homogeneity was also found for the three evaluated factors $(\mathrm{p}=0.5807,0.0536 \mathrm{y}$ 0.4306). There were differences in root weight according to the type of water (ANOVA, F1; $57=4.20, \mathrm{p}=0.0047)$. No differences were found either for the type of soil (ANOVA, F2; $57=0.01, \mathrm{p}=0.8976$ ) or dilution (ANOVA, F3; $57=$ $0.20, p=0.8155)$. The results of Tuckey test showed significant differences when comparing water from cycle 1 , Cycle $3(\mathrm{p}=0.06344)$ and potable water $(\mathrm{p}=$ 0.00925). Despite of the sodium content and salinity found in water obtained from Cycle 3, its application does not causes a significant increase in EC of garden soil (GS) even when is mixed with sand. No values out of the accepted parameters for Lolium perenne crops were found in any of the cases. The content of nitrogen and phosphorus are variable with low concentration of assimilable forms of nitrogen (Table 5). Concerning the available forms of phosphorus (AP), despite the increase in all types of water even with drinking water, this fact did not affect grass growth. This agrees with [2], the addition of assimilable sources of this element does not represent a positive impact in ryegrass biomass. Although the biological mechanisms still unclear and required further studies, the presence of salts $(\mathrm{EC}$ of $3 \mathrm{mS} / \mathrm{cm}$ ) can help intake of nutrients by the plant despite of its concentration in soil [51]. Take into account the results of the present study is important to continue the studies related to the final concentration of this element in soils irrigated with treated water.

Finally Figure 7 presents each of the stages developed to perform the treatment of wastewater and its reuse for greenhouse irrigation. In the upper part we can see the bacteria and fungi that make up the consortia. In the central part, the
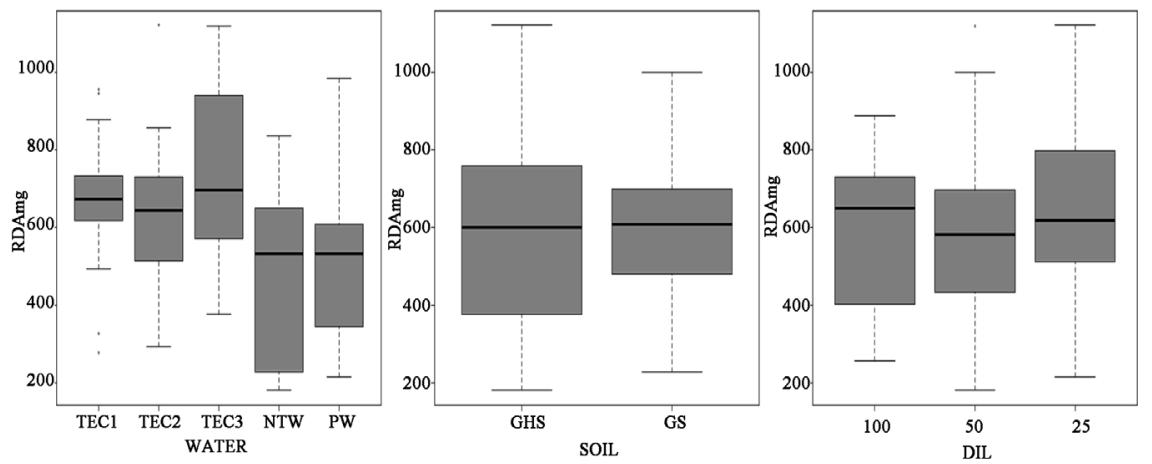

Figure 6. Root biomass of Loliumperenne irrigated with effluents in greenhouse conditions, Measurements 60 days after seeding $(60 \mathrm{~d})$. 
Table 5. Chemical Parameters in soils sedeed with Lolium perenne and irrigated with effluents during $60 \mathrm{~d}$.

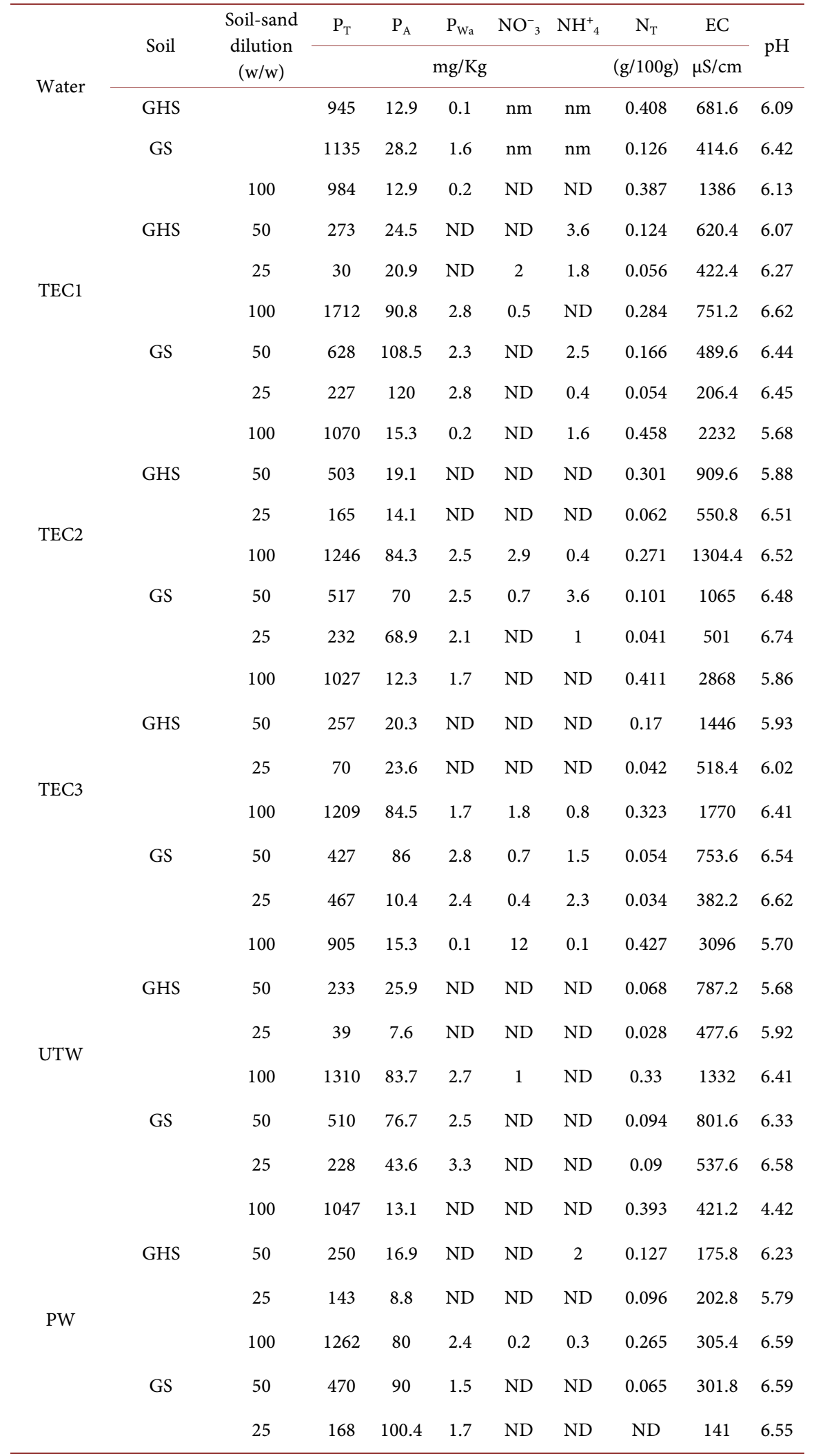

ND: Undetermined. 


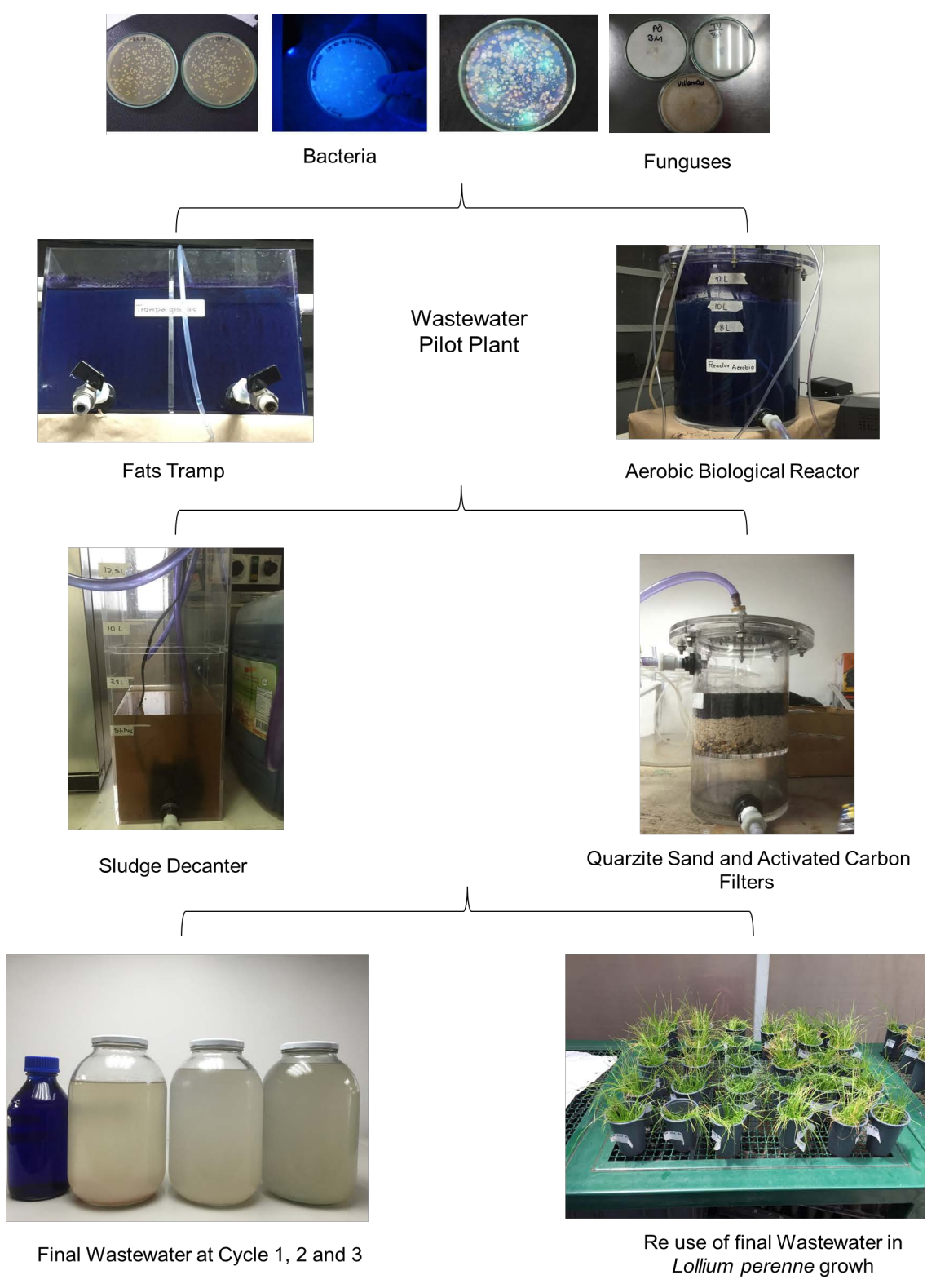

Figure 7. Schematic representation of treatment units at pilot scale and reuse of treated wastewater for Greenhouse re-use test.

four treatment units that are part of the pilot plant are presented. The images of the lower part show the effluents at the end of cycle 1,2 and 3, and the grass plants irrigated and cultivated after 60 days.

\section{Conclusions}

A pilot plant for wastewater treatment was used to evaluate a co-treatment of biological-staining residues and domestic wastewater under non-sterile conditions. Novel microbial consortia are formed by Trametes versicolor, Trametes sp, Pleurotus ostreatus, Pseudomonas fluorescens, Pseudomonas azotoformans, Enterobacter xianfangensis and Bacillus subtillis. 
The dosing 3.5:05 of BSWW and DWW was adequate to perform the co-treatment in the bio-reactor, operating during three consecutive cycles and accumulating a total of $147 \mathrm{~h}$. By mixing the two types of wastewater in the above-mentioned ratio, it was possible to remove more than $90 \%$ of $\mathrm{COD}, \mathrm{BOD}_{5}$ and $\mathrm{CU}$. Additionally, it is possible to affirm that Color, $\mathrm{COD}$ and $\mathrm{BOD}_{5}$ removal were related to adsorption phenomena, the action of ligninolytic enzymes and fungi and bacteria growth. The effluent obtained after the last cycle of treatment (3 cycles) showed a variable salinity and sodium contents. Therefore, the application of this liquid residue will depend on the drainage quality of soil and the capacity of the plants to tolerate moderate to high concentrations of salts.

Finally, biomass of Lolium perenne was higher when post-treated water was used in comparison with untreated wastewater and drinking water. The garden soil combined with quartz sand $(50 \% \mathrm{w} / \mathrm{w})$ did not evidence salinity increases, facilitating its use in soils with good drainage and plants with moderate tolerance to salinity.

\section{Declarations of Interest}

The authors have declared that no conflicting interest exists.

\section{Acknowledgements}

The authors thank the Pontificia Universidad Javeriana and Universidad de La Salle for the financing of this article through Project No. 7135, which is part of the cooperation framework agreement for the development of Science, Technology and Innovation activities signed between the two universities in 2017. The authors thank Jorge Andres Fernández and Edna Viviana Gutierrez Romero for their English editing.

\section{References}

[1] Yang, S., Faisal, I.H., Nghiem, L.D., Nguyen, L.N., Roddick, F. and Price, W.E. (2013) Removal of Bisphenol A and Diclofenac by a Novel Membrane Biorreactor Operated under Non-Sterile Conditions. International Biodeterioration \& Biodegradation, 85, 483-490. https://doi.org/10.1016/j.ibiod.2013.03.012

[2] Morales-Alvarez, E.D., Rivera-Hoyos, C.M., Poveda-Cuevas, S.A., Reyes-Guzman, E.A., Pedroza-Rodriguez, A.M., Reyes-Montaño, E.A. and Poutou-Piñales, R. (2017) Malachite Green and Crystal Violet Decolorization by Ganoderma lucidum and Pleurotus ostreatus Supernatant and by rGlLCC1 and rPOXA 1B Concentrates: Molecular Docking Analysis. Applied Biochemistry Biotechnolology, 184, 794-805.

[3] Spina, F., Cordero, C., Schiliro, T., Sgorbini, B., Pignata, C., Gilli, G., Bicchi, C. and Varese, G.C. (2015) Removal of Micropollutants by Fungal Laccases in Model Solution and Municipal Wastewater: Evaluation of Estrogenic Activity and Ecotoxicity. Journal of Cleaner Production, 100, 185-194. https://doi.org/10.1016/j.jclepro.2015.03.047

[4] Toran, J., Blanquez, P. and Caminal, G. (2017) Comparison between Several Reactors with Trametes versicolor Immobilized on Lignocellulosic Support for the Continuous Treatments of Hospital Wastewater. Bioresource Technology, 243, 966-874. 
https://doi.org/10.1016/j.biortech.2017.07.055

[5] Morato, C.C., Lucas, D., Llorca, M., Mozaz, S.R., Gorda, M., Petrovic, M., Barcelo, D., Vicent, T., Sarra, M. and Marco-Urrea, E. (2014) Hospital Wastewater Treatment by Fungal Biorreactor: Removal Efficiency for Pharmaceuticals and Endocrine Disruptor Compounds. Science of the Total Environment, 493, 365-376.

https://doi.org/10.1016/j.scitotenv.2014.05.117

[6] Fernandez, J.A., Suan, A., Ramirez, J.C., Robles, J., Salcedo, J.C., Pedroza, A.M. and Daza, C. (2016) Treatment of Real Wastewater with $\mathrm{TiO}_{2}$-Films Sensitized by a Natural-Dye Obtained from Picramnia sellowii. Journal Environmental Chemical Engineering, 4, 2848-2856. https://doi.org/10.1016/j.jece.2016.05.037

[7] Garcia, J.C., Pedroza, A.M. and Daza, C.E. (2017) Magnetic Fenton and Photo-Fenton-Like Catlysts Supported on Carbon Nanotubes for Wastewater Treatment. Water, Air, \& Soil Pollution, 228, 246.

[8] MADS (Ministerio de Ambiente y Desarrollo Sostenible) (2015) Resolución 0631 por la cual se establecen los parámetros y los valores limites máximos permisibles en los vertimientos puntuales a cuerpos de aguas superficiales y a los sistemas de alcantarillado público y se dictan otras disposiciones, Colombia.

http://www.minambiente.gov.co/images/normativa/app/resoluciones/d1-res_631_ marz_2015.pdf

[9] SDA (Secretaría Distrital de Ambiente) (2009) Resolución 3957 por la cual se establece la norma técnica, para el control y manejo de los vertimientos realizados a la red de alcantarillado público en el distrito capital, Bogota, Colombia.

http://www.bogotaturismo.gov.co/sites/intranet.bogotaturismo.gov.co/files/RESOL UCI\%C3\%93N\%203957\%20DE\%202009.pdf

[10] MADS (Ministerio de Ambiente y Desarrollo Sostenible) (2014) Resolución 1207 por la cual se adoptan disposiciones relacionadas con el uso de aguas residuales tratadas, Bogota, Colombia.

http://www.minambiente.gov.co/images/GestionIntegraldelRecursoHidrico/pdf/nor mativa/Res_1207_2014.pdf

[11] Lu, Z., Sun, X., Yang, Q., Li, H. and Li, C. (2009) Persistence and Functions of a Decolorizing Fungal Consortium in a Non-Sterile Biofilm Reactor. Biochemical Engineering Journal, 46, 73-78. https://doi.org/10.1016/j.bej.2009.04.017

[12] Fabregat, M.B., Lucas, D., Tuomivirta, T., Fritze, H., Pennanen, T.S., Rodriguez-Mozaz, R., Barcelo, D., Caminal, G. and Vicent, T. (2017) Study of the Effect of the Bacterial and Fungal Communities Present in Real Wastewater Effluents on the Performance of Fungal Treatments. Science of the Total Environment, 579, 366-377. https://doi.org/10.1016/j.scitotenv.2016.11.088

[13] Arantes, V., Milagres, A.M.F., Filley, T.R. and Goodell, B. (2011) Lignocellulosic Polysaccharides and Lignin Degradation by Wood Decay Fungi: The Relevance of Nonenzymatic Fenton-Based Reactions. Journal of Industrial Microbiology and Biotechnology, 38, 541-555. https://doi.org/10.1007/s10295-010-0798-2

[14] Cheng, Z., Xiang-Hua, W. and Ping, N. (2013) Continous Acid Blue 45 Decolorization by Using a Novel Open Fungal Reactor System with Ozone as the Bactericide. Biochemical Engineering Journal, 79, 246-252. https://doi.org/10.1016/j.bej.2013.08.010

[15] Wood, P.M. (1994) Pathways for Production of Fenton's Reagent by Wood-Rotting Fungi. FEMS Microbiology Reviews, 13, 313-320. https://doi.org/10.1111/j.1574-6976.1994.tb00051.x

[16] Joseleau, J.P., Gharibian, S.J., Comtat, L.A. and Ruel, K. (1994) Indirect Involve- 
ment of Ligninolytic Enzyme Systems in Cell Wall Degradation. FEMS Microbiology Reviews, 13, 255-263.

[17] Hammel, K.E., Kapich, A.N., Jenses, K.A. and Ryan, Z.C. (2002) Reactive Oxygen Species as Agent of Wood Decay by Fungi. Enzyme and Microbial Technology, 30, 445-453. https://doi.org/10.1016/S0141-0229(02)00011-X

[18] Solis, M., Solis, A.M. and Peres, H.I. (2012) Microbial Discoloration of Azo Dyes: A Review. Process Biochemistry, 47, 1723-1748. https://doi.org/10.1016/j.procbio.2012.08.014

[19] Khouni, I., Marrot, B. and Ben, R. (2012) Treatment of Reconstituted Textile Wastewater Containing a Reactive Dye in an Aerobic Sequencing Batch Reactor using a Novel Bacterial Consortium. Separation and Purification Technology, 87, 110-119. https://doi.org/10.1016/j.seppur.2011.11.030

[20] Saratale, R., Saratale, G., Ghang, J. and Govindwar, S. (2011) Bacterial Decolorization and Degradation of Azo Dyes: A Review. Journal of the Taiwan Institute of Chemical Engineers, 42, 138-157. https://doi.org/10.1016/j.jtice.2010.06.006

[21] Tuttolomondo, M., Solange, G., Desimone, M. and Díaz, L. (2014) Removal of Azo Dyes from Wáter by Sol-Gel Immobilizied Pseudomonas sp. Journal of Environmental Chemical Engineering, 2, 131-136. https://doi.org/10.1016/j.jece.2013.12.003

[22] Shreve, M.J., Brockman, A., Hartleb, M., Prebihalo, S., Dorman, F.L. and Brennan, R.A. (2016) The White-Rot Fungus Trametes versicolor Reduces the Estrogenic Activity of a Mixture of Emerging Contaminants in Wastewater Treatment Plant Effluent. International Biodeterioration \& Biodegradation, 109, 132-140. https://doi.org/10.1016/j.ibiod.2016.01.018

[23] Ferraz, F.M., Povinelli, J., Pozzi, E., Vieira, E.M. and Trofino, J.C. (2014) Co-Treatment of Landfill Leachate and Domestic Wastewater using a Submerged Aerobic Biofilter. Journal of Environmental Management, 141, 9-15. https://doi.org/10.1016/j.jenvman.2014.03.022

[24] Ferraz, F.M., Bruni, A.T., Povinelli, J. and Vieira, E.M. (2016) Leachate/Domestic Wastewater Aerobic Co-Treatment: A Pilot-Scale Study using Multivariate Analysis. Journal of Environmental Management, 166, 414-419. https://doi.org/10.1016/j.jenvman.2015.10.034

[25] Koch, E.D., Honig, J., Vaiciunas, J., Meyer, W.A. and Bonos, S.A. (2017) Effect of Endophyte on Salinity Tolerance in Perennial Ryegrass. International Turfgrass Society Research Journal Abstract-Genetics and Breeding, 13, 459-461.

[26] Harivandi, M.A., Butler, J.D. and Wu, L. (1992) Salinity and Turfgrass Culture. In: Turfgrass Agronomy Monograph 32, American Society of Agronomy, Crop Science Society of America, Soil Science Society of America, 207-229.

[27] Morales-Alvarez, E.D., Rivera-Hoyos, C.M., Gonzales-Ogliastri, N., Rodriguez-Vasquez, R., Poutou-Piñales, R.A., Daza, C.E. and Pedroza-Rodriguez, A.M. (2016) Partial Removal and Detoxification of Malachite Green and Crystal Violet from Laboratory Artificially Contaminated Water by Pleurotus ostreatus. Universitas Scientiarum, 21, 259-285. https://doi.org/10.11144/Javeriana.SC21-3.prad

[28] Meza, R.A., Monroy, A.F., Mercado, M., Poutou, R.A., Rodríguez, P. and Pedroza, A.M. (2004) Study of Stability in Real Time of Cryopreserved Strain Banks. Universitas Scientiarum, 9, 35-42.

[29] Tinoco, R., Pickard, M.A. and Vazquez-Duhalt, R. (2001) Kinetic Differences of Purified Laccases from Six Pleurotus ostreatus Strains. Letter in Applied Microbiology, 32, 331-335. https://doi.org/10.1046/j.1472-765X.2001.00913.x

[30] Santoyo, F., González, A.E., Terrón, M.C., Ramírez, L. and Pisabarro, A.G. (2008) 
Quantitative Linkage Mapping of Lignin-Degrading Enzymatic Activities in Pleurotus ostreatus. Enzyme and Microbial Technology, 43, 137-143. https://doi.org/10.1016/j.enzmictec.2007.11.007

[31] Tien, M. and Kirk, T. (1983) Lignin Degradation Enzyme from the Hymenomycete. Phanerochaete chrysosporium burds. Science, 221, 661-663. https://doi.org/10.1126/science.221.4611.661

[32] American Public Health Association (APHA) (1992) Standard Methods for the Examination of Water and Wastewater. 18th Edition, American Public Health Association, Washington DC.

[33] Pallerla, S. and Chambers, R. (1997) Characterization of a Ca-Alginated-Inmovilized Trametes versicolor Bioreactor for Decolorization and AOX Reduction of Paper Mill Effluents. Bioresource Technology, 60, 1-8. https://doi.org/10.1016/S0960-8524(96)00171-X

[34] Rojas-Higuera, N.S., Pava-Sanchez, A.M., Pinzon Rangel, D.L., Diaz-Ariza, L.A., Quevedo-Hidalgo, B. and Pedroza-Rodriguez, A.M. (2016) Bio-Transformed Sawdust by White Rot Fungi used as a Carrier for Plant Growth-Promoting Bacteria. European Journal of Wood and Wood Products, 75, 263-273.

[35] Tang, J., Yu, X., Luo, N., Xiao, F., Camberato, J.J. and Jiang, Y. (2013) Natural Variation of Salinity Response, Population Structure and Candidate Genes Associated with Salinity Tolerance in Perennial Ryegrass Accessions. Plant Cell \& Environmental, 36, 2021-2033.

[36] Guisande, C., Vaamonde, A. and Barreiro, A. (2014) RWizard Software. Universidad de Vigo. http://www.ipez.es/rwizard/

[37] Bray, R.H. and Kurtz, L.T. (1945) Determination of Total, Organic, and Available Forms of Phosphorus in Soils. Soil Science, 59, 39-45. https://doi.org/10.1097/00010694-194501000-00006

[38] Bremmmer, J.M. (1996) Nitrogen-Total. In: Bigham, J.M., Sparks, J.M., Page, D.L., Helmke, A.L., Loeppert, P.A., Soltanpour, R.H., et al., Eds., Methods of Soil Analysis, Part 3, Soil Science of America, American Society of Agronomy, Wyoming, $1085-1122$.

[39] Mulvaney, R.L. (1996) Nitrogen-Inorganic Forms. In: Bartels, J.M., Bigham, J.M., Sparks, D.L., Page, A.L., Helmke, P.A., Loeppert, R.H., et al., Eds., Soil Science of America, American Society of Agronomy, Wyoming, 1123-1184.

[40] Mojiri, A., Ziyang, L., Tajaddin, R.M., Farraji, H. and Alifar, N. (2016) Co-Treatment of Landfill Leachate and Municipal Wastewater using the ZELIAC/Zeolite Constructed Wetland System. Journal of Environmental, Management, 166, 124-130. https://doi.org/10.1016/j.jenvman.2015.10.020

[41] Monsalve, S.O., Dornelles, J., Poll, E., Ramirez, M., Valente, P. and Gutterres, M. (2017) Biodecolourisation and Biodegradation of Leather Dyes by a Native Isolate of Trametes villosa. Process Safety Environmental Protection, 109, 437-451. https://doi.org/10.1016/j.psep.2017.04.028

[42] Martinko, M. and Clark, S. (2014) Clark, Brock Biology Microorganisms. 14th Edition, Benjamin Cummings, San Francisco.

[43] Puentes, I.J., Pedroza, A.M., Navarrete, M., Villegas, T.L. and Cristiani, E. (2012) Biosorption of Trivalent Chromium from Aqueous Solutions by Pleurotus ostreatus Biomass. Environmental Engineering Management Journal, 11, 1741-1752.

[44] Castillo, L.C., Pedroza, A.M. and Barragan, E.B. (2012) Adsorption and Biological Removal of Basic Green 4 Dye using White-Rot Fungi Immobilized on Agave Tequilana Weber Waste. Fresenius Environmental Bulletin, 22, 2334-2343. 
[45] España-Gamboa, E., Vicent, T., Font, X., Dominguez-Maldonado, J., Canto-Canché, B. and Alzate-Gaviria, L. (2017) Pretreatment of Vinasse from the Sugar Refinery Industry under Non-Sterile Conditions by Trametes versicolor in a Fluidized Bed Bioreactor and Its Effect when Coupled to an UASB Reactor. Journal of Biological Engineering, 11, 6.

[46] Hernández, D. (2017) Evaluación de un consorcio fúngico/bacteriano en el tratamiento de aguas residuales producidas en las prácticas de microbiología. B.Sc. Thesis, Pontificia Universidad Javeriana. Bogotá.

[47] Xiong, X., Wen, X., Bai, X. and Qian, Y. (2008) Effects of Culture Conditions on Ligninolytic Enzymes and Protease Production by Phanerochaete chrysosporium in Air. Journal of Environmental Science, 20, 94-100. https://doi.org/10.1016/S1001-0742(08)60014-5

[48] Rivera, C.M., Morales, E.D., Poutou, R.A., Pedroza, A.M., Rodriguez, R. and Delgado, J.M. (2013) Review Fungal Laccases. British Mycological Society, 30, 1-16.

[49] Aydogmus, R., Depci, T., Sarikaya, M., Kul, A.R. and Onal, Y. (2016) Adsorption of Crystal Violet on Activated Carbon Prepared from Coal Flotation Concentrate. IOP Conference Series. Earth and Environmental Science, Toronto, 1-3 November 2017, Vol. 44, 1-5. https://doi.org/10.1088/1755-1315/44/5/052022

[50] Maneerung, T., Liew, J., Dai, Y., Kawi, S., Chong, C. and Wang, C. (2016) Activated Carbón Derived from Carbon Residue from Biomass Gasification and Its Application for Dye Adsorption: Kinetics, Isotherms and Thermodynamic Studies. Bioresource Technology, 200, 350-359. https://doi.org/10.1016/j.biortech.2015.10.047

[51] Liang, Y., Zhu, H., Bañuelos, G., Yan, B., Shutes, B., Cheng, X. and Cheng, X. (2017) Removal of Nutrients in Saline Wastewater using Constructed Wetlands: Plant Species, Influent Loads and Salinity Levels as Influencing Factors. Chemosphere, 187, 52-61. https://doi.org/10.1016/j.chemosphere.2017.08.087 